\title{
Introduction: The Roots of Jewish Radicalism
}

\section{The Rationale}

Why are Jews radicals? Why do they work against their class interests? This has nonplussed Republican experts for decades. The percentages may vary from $60-90 \%$, but Jews are always way over $50 \%$ for Democrats and progressives. The reasons are many and go back to Jewish history. I summarize them below, based on the late historian Robert S. Wistrich in his masterful book, Revolutionary Jews from Marx to Trotsky, in his opening chapter, "Jews and Socialism":

1. Jews are outsiders;

2. Jews have the prophetic tradition;

3. Jews care about the oppressed, the disabled, the widowed, and the orphaned;

4. Jews go against their class interests; in Marxian terms, they live like capitalists yet vote like proletarians.

\section{The History: 1881-1914}

The grandparents and great-grandparents of today's radicals came to America from Russia and Poland for the most part. True, there were smaller numbers of German and Sephardic Jews, but the vast majority of American (and world Jewry) came from Eastern Europe and brought with them a variety of radical ideologies (Marxism, Socialism, Communism, Bundism, Labor Zionism), as did many other Europeans (Italians such as Sacco and Vanzetti, Greeks, Scandinavians, Germans). 
xvi $\mid$ Introduction: The Roots of Jewish Radicalism

They came to the impoverished urban centers-Jews are urban people; they did not go to the mines and forests of Maine or Pennsylvania or to the wild west of Colorado or Wyoming or Texas, but to urban centers like New York, Philadelphia, Chicago, Cleveland, and Milwaukee-the Lower East Side of Manhattan, the West End of Boston, the South Side of Chicago, the "Inner City" of Milwaukee.

Their language was Yiddish, not Hebrew or German, and they began to "organize." In 1907, the United Hebrew Trades comprised 74 affiliated unions and 50,000 members. By 1914, it had soared to 104 unions and over 250,000 members. The Jewish unions were the backbone of the Socialist Party of America, which had its own Yiddish-speaking wing.

The radical Yiddish press-communist, anarchist, socialist, Zionist, anti-Zionist, Bundist, religious or secular-was all widely read and influential. The largest publication was Abraham Cahan's The Jewish Daily Forward, which reached over 200,000 readers in 1916.

Yiddish writers such as Shalom Asch, Isaac Bashevis Singer, and Shalom Aleichem were widely read. Yiddish theater flourished. Today there is an English-language newspaper, The Forward, and a small Yiddish Forward. Only Orthodox Jews have larger Yiddish-speaking readers and press.

Socialist mayors were elected in Milwaukee as early as 1916 and as late as 1951 (Frank Zeidler). They were called "sewer socialists," more interested in fixing the roads and bridges than engaging in "permanent revolution," and they were beloved. Madison, Wisconsin, has a socialist (and Jewish) mayor to this day, Paul Soglin.

\section{After the Russian Revolution: 1917-1939}

After the successful revolt by Communists in the Soviet Union, communism grew all over the world, and with it, Jewish participation. In fact, many of the early Communist leaders-Leon Trotsky, Lazar Kaganovich, and even Vyacheslav Molotov's wife-were renegade Jews. In fact, Marxism became known as a substitute religion for secular Jews and non-Jews, with Marx as God and Lenin as Moses the Prophet.

Sociologist Nathan Glazer estimated that fully one-third of the American Communist Party was Jewish-or about 15,000; and if you added "fellow travelers"-admirers, spouses and friends-easily ten times that. Communists were active in all aspects of American life and especially in trade unions, from teachers to longshoremen. 
Communism was also very attractive to intellectuals, both literary and cinematic. New York, Chicago, and Los Angeles had large numbers of Communist members, especially in the movie industry. Walt Disney was shocked when his illustrators of Minnie and Mickey and Donald Duck walked out on strike, desiring higher wages and better health benefits.

\section{The Decline of the Old Left: 1939-1959}

Several events traumatized and confused the Old Left:

1. The Molotov-Ribbentrop Pact of 1939. The so-called Hitler-Stalin Pact was a tremendous blow to the morale of the Communist and Socialist parties. How could Stalin make "peace" with this fascist?

2. The Establishment of the State of Israel. While the Soviet Union did recognize the nascent state in 1948-1949, the honeymoon was short-lived as they moved onto support for the Arab League. This left the Old Left fumbling for a rationale. Should they be Zionists and supporters of Israel or toe the party line against Israel? Many compromised by supporting Israel but rejecting Zionism as defined as Israel being the center of Jewish life. America, England, or whatever diaspora country they were in would be the center of their lives, but they would support Israel financially, politically, and emotionally.

3. The Hard Line of the Communist Party. This was the famous struggle between the Stalinist Left that hewed to a tough Communist line and the Trotskyite and other offshoots that desired a softer, more flexible line. In many ways it was the difference between a strict religious cult (Stalinism) and a more flexible approach to life.

4. A Powerful Anti-Left Suppression. This included Communists and Socialists losing their jobs, being blackballed, jailed, and even murdered. This movement was called McCarthyism, named after Senator Joe McCarthy, ironically from the progressive state of Wisconsin.

\section{The Silent Years: The 1950s}

Best epitomized by such movies as Rebel Without a Cause and Invasion of the Body Snatchers, the 1950s were a time of defensiveness, caution, 
xviii | Introduction: The Roots of Jewish Radicalism

isolationism and conformity and were filled with anti-Communist jingoism. Red-baiting, homophobia, racism, fear of the atomic bomb, and anti-Semitism all merged together, and at times led by such hypocrites and self-loathing men as Roy Cohn, who was both Jewish and gay. Cohn, who ironically bridged the generation to Donald Trump, led the charge against "commie Jews" and "fags." People wanted "normalcy" and quiet. With increased affluence, people left the ghettos of the inner cities and moved to the suburbs. People tried to keep a low profile.

Yet the 1950s teemed with resentment-African-Americans, rebels, hipsters, rock-and-roll. Things were going to burst.

\section{The Radical Years: 1963-1971}

It took a while, and it came as a surprise, but after John F. Kennedy, Malcolm X, Martin Luther King Jr., and Robert F. Kennedy were assassinated, the ghettos exploded and, soon after, the campuses exploded into riot and protest.

What was the difference between the Old Left and the New Left?

What were the divisions within the New Left between hippies, Yippies (Youth International Party members), and radicals? Between blacks and whites? Women and men? Gays and straights?

Why were there so many Jews in the radical movements?

All of these questions I have tried to answer in this book, through my essays from the '60s and '70s.

\section{Post-1967: The Rise of Jewish Radical Movements}

Why did specifically Jewish radical movements arise in 1967, after the Israeli-Arab Six-Day War? That was the crucial year. They arose as a reaction to the growing anti-Israel and anti-Semitic sentiments of black and white radical groups such as the Black Panthers, the Nation of Islam, and Students for a Democratic Society (SDS). I collected the writings of such newborn Jewish radical groups in my classic book Jewish Radicalism, which came out in 1973.

What exactly did these radical Jewish movements do?

Freedom Seders, Soviet Jewish Rallies, Trees for Vietnam, the rise of Jewish studies, collectives, chavurot, new forms of prayer and traditions, more democracy in the Jewish community, new roles for women and 
gays-all of these were examples of the new times. Basically, these Jewish groups were transforming the Jewish community just as their non-Jewish counterparts were transforming the rest of the nation.

\section{The Conservative Reaction: Post-1967}

There is an old Yiddish expression: Azes Christlizich, iz Yiddlezich. Roughly it means, "As the Christians do, so too will the Jews." That is, as non-Jews respond to events, eventually Jews would do the same, and often in the same manner.

Just as the "hard-hat" working-class Americans, the so-called "Silent Majority," arose in the late '60s in reaction to the rise of radical movements, so too did right-wing Zionist and neo-conservative Jews arise. They quietly did their thing, and while it took a decade or two they eventually showed their strength with the election of Ronald Reagan, and then, thirty-six years later, of Donald Trump. Liberals and the radicals were asleep at the wheel and were caught by surprise by this conservative reaction.

Just as the radical Left arose in the post-June 1967 period, after the victory in Israel, with strong opposition to Israel's "arrogance" and "colonization" of the West Bank, Golan Heights, Sinai, and Gaza, so too did a radical Right arise in Israel ( $i k k$ kud) and in the United States (Jewish Republicans) to oppose the general Left and the Jewish Left. While most Jews saw Israel's 1967 victory as a great event that "saved" Israel from destruction by Arab armies, some saw the opposite-the beginning of the occupation of the West Bank and the "oppression" of the Palestinian people.

Three things happened to me on June 5, 1967, that had a profound effect on my life.

One, I had graduated with a B.A. from the University of WisconsinMilwaukee and was accepted to the sociology Ph.D. program at Northwestern University in Evanston, Illinois. I became a radical sociologist.

Two, I took my first and only "acid trip" at a graduation party on the East Side of Milwaukee. It had a profound effect on my mind, so profound that I told myself it would be my last "trip" - it was simply too powerful. I'm glad I did, or else I would not be here to write these memoirs. I would have been dead or strung out.

Three, the Israeli-Arab Six-Day War began June 5 with Israel's surprise attack to the Arabs, the destruction of their airfields, and their surge across the "green line" into Sinai and the West Bank. Never had there been so 
much jubilation and so few deaths. I remember my father and others wanting to send their sons and daughters to Israel to fight. Never had so much money been collected for Israel. It was a heady time.

But, as noted, there was an almost immediate reaction from the radical Left condemning Israel. This was the beginning of anti-Zionism and anti-Israel sentiment on campuses. It was at the time of the 1967 Six-Day War that I and a few others at Northwestern University founded the Jewish Student Movement, a radical Jewish movement that was progressive-we supported the black civil rights movement, we opposed the war in Vietnam, and we fought against poverty and wild capitalism, but we also supported Israel's right to exist.

This middle way was often difficult and set us up against other radicals who happened to be Jewish. Out of this tension came my book Jewish Radicalism and my many other articles on Jewish student activism, racism, and the war in Vietnam (several of them found in this book).

But disaffection with the Left had begun. Norman Podhoretz, in his many books including Doings and Undoings, Breaking Rank, and my favorite, Ex-Friends, showed how the "Old Left" split into two campsStalinists who supported Stalin despite his pact with Hitler in 1939 (the Molotov-Ribbentrop Pact) and his anti-Semitism (the Doctor's Plot, the killing of Jewish intellectuals, etc.), and Trotskyites who opposed Stalin and wanted continuous revolution.

This was the first major split within the Communist Party. The second split came when Podhoretz, Irving Kristol, and to some extent Nathan Glazer, Daniel Bell, Martin Peretz, and others opposed the New Left and their literary "fellow travelers" (Norman Mailer, Allen Ginsberg, William Burroughs).

In so doing they also opposed the Jewish Left such as our group. This opposition was carried out in the pages of Commentary magazine but also in The New Republic under Martin Peretz and Leon Wieseltier. The opposition to the Left and the Jewish Left has become more sophisticated and continues to this day. One of the best examples of this neo-con critique is Jonathan Neumann's 2018 book To Heal the World? How the Jewish Left Corrupts Judaism and Endangers Israel.

This is a brilliant book in many ways, one of the few that dares attack and criticizes in a cogent and disciplined way, using traditional Jewish sources, Jewish Left thinkers such as Michael Lerner and Art Green, as well as groups like Breira, New Jewish Agenda, and Jewish Voice for Peace. 
The title of the book is important. The question mark in the title says that "healing the world"-in Hebrew, tikkun olam-is actually not emphasized in the Bible. Neumann uses religious and political history as well as Biblical exegesis to debunk this idea and shows how the Bible was twisted by Jewish radicals and liberals to support a left-wing agenda.

Moreover, he believes Judaism based solely on tikkun olam, on social justice projects, leads to assimilation. It is not a firm basis for Jewish continuity. Example: despite all of the social justice projects in synagogues across the country, the intermarriage rate continues to soar. It is now over $70 \%$. In short, all of these liberal projects, from climate control to helping immigrants, do nothing to stop the slow road to Jewish extinction as a people, according to Neumann.

Furthermore, tikkun olam also endangers Israel. Our first priority, Neumann says, must be a concern for the safety, security, welfare, and survival of the Jewish community here in the West and in Israel, not Native Americans, Darfurians, transgender people, Palestinians, and other "oppressed." This is the old Jewish struggle between particularism and universalism. Who should I be for?

It is at the heart of Hillel the Elder's famous injunction: "If I am not for myself, who will be for me? But if I am only for myself, what am I? And if not now, when?" (Ethics of the Fathers, I, 14). It is a never-ending struggle to balance one's needs with those of others.

\section{Today's Radicals}

My generation, with few exceptions (David Horowitz, for example), has continued to promote progressive causes. Though confused and battered by Israel's and this country's turn to the Right, we have not sold out. But what about the younger generation of Jews, the so-called millennials, those born since 1980 or even 2000 ? Are they still radical?

Neo-con Norman Podhoretz was confused, frustrated, and mystified that so few Jews followed him. In fact, he wrote a book called Why Are Jews Liberal? And we now have a Jewish guy named Bernie Sanders, an outspoken socialist and Jew, running for President and reaching crowds of 25,000 or more in the year 2020. The majority of Jews will always be progressive, liberal and radical. The numbers may fluctuate, but it will always be that way. We may even have a Jewish socialist President of the United States. Who could have imagined it? 


\section{Sources}

Buhle, Mari Jo, Paul Buhle, and Dan Georgakas (eds.). Encyclopedia of the American Left. Chicago and London: St. James Press, 1990. A comprehensive history and sociology of the American Left from abortion to Di Zukunft (a Yiddish-language newspaper founded in 1890 and still in existence).

Farber, David. The Age of Great Dreams: America in the 1960s. New York: Hill and Wang, 1994. Written by a Barnard College historian, this is a lucid and thoughtful account.

Gitlin, Todd. The Sixties: Years of Hope, Days of Rage. New York: Bantam Books, 1987. Written by a sociologist and former SDS leader, this is an honest account of the radical '60s.

Guttmann, Allen. The Jewish Writer in America. New York: Oxford University Press, 1971. (See especially pp. 134-177, on "Jewish Radicals.") The uniqueness of Guttmann's book is that he is one of the few to describer and analyze literary, rather than political, radicals, people like "proletarian" writers such as Abraham Cahan, Michael Gold, Howard Fast, Paul Goodman, Norman Mailer, and Allen Ginsberg. A very important book.

Liebman, Arthur. Jews and the Left. New York: John Wiley, 1979. According to Morris U. Schappes, this book is a "tremendously informative, often illuminating and extensive sociological study" (Jewish Currents, September 1979, pp. 18-20, and Liebman's response in the January 1980 issue, p. 38). For a very different and naturally critical review, see Bernard K. Johnpoll in Commentary, September 1979, pp. 92-94. Another critical review is by Brandeis professor Stephen J. Whitfield in Transaction/Society, July/August 1980, pp. 83-86, but at least they took the time and space to review it. The book is nearly 700 pages long.

Miller, James. Democracy in the Streets: From Port Huron to the Siege of Chicago. Cambridge, Mass.: Harvard University Press, 1994. Written by a professor of political science, this is an accurate and original account of the rise of the New Left.

Neumann, Jonathan. To Heal the World? How the Jewish Left Corrupts Judaism and Endangers Israel. New York: St. Martin's Press, 2018.

Newfield, Jack. The Prophetic Minority: A Probing Study of the Origins and Development of the New Left. New York: Signet Books, 1966. Written before the rise of the radical Jewish movement by a veteran journalist, this book was one of the first and possibly the best single volumes on the rise of the New Left.

Podhoretz, Norman. Ex-Friends. San Francisco: Encounter Books, 2000. The subtitle is "Falling Out with Allen Ginsberg, Lionel and Diana Trilling, Lillian Hellman, Hannah Arendt, and Norman Mailer." This is his wistful, not spiteful, polemic against his former leftist friends and contains rare accounts of his encounters with these literary lights as well as a brilliant (and he is indeed a brilliant writer-I love his construction of sentences) redaction of the radical Left, Old and New. Also see his other books: Making It, Breaking Ranks, Doings and Undoings, and Why Are Jews Liberals? 
Porter, Jack Nusan, and Peter Dreier (eds.). Jewish Radicalism: A Selected Anthology. New York: Grove Press and Random House, 1973. My classic movement anthology on Jewish radicals and radical Jews.

(ed.). The Sociology of American Jews: A Critical Anthology. Lanham, Md.:

University Press of America, 1978. Inspired by Morris Schappes' history of American Jewry from a socialist point of view (though the word "socialist" was taboo then, and even in my generation; I used the word "critical" or "radical"), this was, as Marshall Sklare told me, the first time the words "sociology of American Jewry" were used in a title. See especially the essays on Vietnam and the Jews by Diane Winston and the Jewish Labor Movement by Jerry Habush.

Sanders, Bernie. Our Revolution: A Future to Believe In. New York: Thomas Dunne Books, 2016.

Wakefield, Dan. New York in the Fifties. Boston and New York: Houghton Mifflin-Seymour Lawrence, 1992. The '50s were neither as dull nor as plastic as people thought, and in many ways, to understand the '60s (civil rights, democratic socialism, the hippies), you have to understand the '50s (sit-ins, the atom bomb, McCarthyism, the Beats). Wakefield knew everybody from C. Wright Mills to Marion Magid.

Wellstone, Paul. The Conscience of a Liberal: Reclaiming the Compassionate Agenda. New York: Random House, 2000. The late U.S. senator from Minnesota had a tremendous impact on such senators as Amy Klobuchar, Elizabeth Warren and Bernie Sanders. See the excellent biography by Antonia Felix, Elizabeth Warren: Her Fight, Her Work, Her Life, Naperville, Ill.: Sourcebooks, 2018.

Wistrich, Robert S. Revolutionary Jews from Marx to Trotsky. New York: Barnes \& Noble, 1976. Written by one of the finest British historians, who died much too soon (his later works dealt with anti-Semitism), this book is the best single-volume analysis of radical Jews from Marx to Trotsky. (Especially see pp. 1-22 on the Jewish attraction to socialism and other radical thought.) 
